\title{
The Geography of Manchuria
}

\author{
By Robert Burnett Hall \\ University of Michigan, Ann Arbor, Michigan
}

$\mathrm{T}$ THE term "Manchuria" is applied in a more or less vague way to the northeasternmost territories of China, and embraces all lands lying east of Mongolia and northeast of the Great Wall. Manchuria, as here used, applies to the Eastern Three Provinces ('Tungsanshin) of Heilungkiang (Amur), Kirin (Chilin) and Fengtien (Mukden or Liaoning), and the Japanese leased territory of Kwantung and the special Barga (Hulunpeierh) District on the northwest frontier. It forms a roughly triangular area of about 380,000 square miles. ${ }^{1}$

The border lands of Manchuria, except where the broad valley of the Liao River reaches the sea and in the northwest, where the extensive steppe lands of the Great Khingan piedmont make up the Barga District, are composed of broad mountain masses. These are for the most part densely clad in virgin forest and contain the bulk of all Chinese timber reserves. Here are found minerals of several kinds and the broader valleys offer excellent agricultural and grazing lands. Enclosed by these mountain barriers is the great Manchurian Plain, originally a grassland, where agricultural production and potentialities, coupled with a sparse population, have earned for the area the titles of the "Grain basket of Asia" and the "Land of the Bean." In fact, the Manchurian Plain constitutes practically the only extensive area

1 The exact area of Manchuria is not known. Between the maximum and minimum estimates there is a difference of 119,833 square miles. Chu Hsiao, in Manchuria, pp. 2-4, 1929, makes a comprehensive consideration and the figure of 380,000 square miles is accepted as approximately correct. of middle latitude grassland still undeveloped. Its soils are of great fertility and the long, dry, severe winters and hot, rainy summers are admirably suited to spring-sown cereals and legumes.

\section{The Climate of Manchuria}

The climate of Manchuria has often been described as continental in its seasonal fluctuations of temperature, and monsoonal in its régime of rainfall. According to the Köppen system, ${ }^{2}$ three types of climate may be recognized, i.e., Dwa, Dwb and BSkw. The first occupies approximately the southern two-thirds of Manchuria, and is a cold, dry, winter type, with the summer hot and sufficiently rainy to permit forest growth. The mean temperature of the coldest month is below $3^{\circ} \mathrm{C}$., and of the warmest month, over $22^{\circ} \mathrm{C}$. The Dwb varies from the preceding only in that the warmest month is below $22^{\circ} \mathrm{C}$. It occurs in Heilungkiang and eastern Kirin. These Dw types are found in no other part of the world. The southern part of the Barga District has the BSkw, or cold steppe-dry winter climate. Here precipitation is very low, and the mean annual temperature is below $18^{\circ} \mathrm{C}$., but the warmest month is over $18^{\circ} \mathrm{C}$. Winter is the dry period. ${ }^{3}$

2 Köppen, W., Die Klimate der Erde, 1923. Part 2, Das geographische System der Klimate.

${ }^{3}$ de Martonne, Emm., Traité de Géographie Physique, 4 ed., pp. 229-261, 1925, recognizes a Manchurian type (D6) which has a mean annual temperature under $10^{\circ} \mathrm{C}$. with the rainy season during summer.

Sion, Jules, Asie des Moussons, Tome 9, Géographie Universelle, Chap. 1, 1928, also recognizes a Manchurian type for all of Manchuria 
Manchuria lies between the great continental interior, with its extremes of pressure, and the sea. In summer, there is a well-developed low pressure area over inner Asia, and moistureladen winds flow inland. These are best developed in July and August, and bring precipitation in the form of rain. In south Manchuria, all stations indicate an annual average precipitation of over $600 \mathrm{~mm} .{ }^{4}$ with over fifty per cent occurring in July and August, and at least seventy per cent falling during the growing season. Much the same condition is indicated in central Manchuria. ${ }^{5}$ In general, precipitation decreases northward. The northern edge of the plain receives less than $600 \mathrm{~mm}$. The eastern slopes of the Changpai Range, near Korea, receive over 800 $\mathrm{mm}$. The steppe land of Barga, due to its lying in the rain shadow of the Great Khingan, and the eastern slopes of the southern Great Khingan, due to the barrier presented by the hill land of Jehol, receive under $400 \mathrm{~mm}$. The remaining mountain country all re-

east of the Great Khingans. This he describes as very cold winter ( $\mathrm{Jan}$. mean temp. at Mukden $\longrightarrow 13^{\circ} \mathrm{C}$.) but quite warm in summer (July mean at Mukden-24 $24^{\circ} .2 \mathrm{C}$.) with precipitation sufficient to grow wheat. Chu Coching, Climatic Provinces of China, Memoir 1, p. 10, Inst. of Meteorology, Nanking, 1929, similarly recognizes a Manchurian type. In this he includes all of Manchuria except the extreme western part. The criteria are as follows: At least five months with a mean temperature below $0^{\circ} \mathrm{C}$, and mean annual below $10^{\circ} \mathrm{C}$. The growing season is limited to five or six months; winter is extremely cold. Annual precipitation varies from 40 to $60 \mathrm{~cm}$. Half of it falls in July and August. The $40 \mathrm{~cm}$ isohyetal marks the western boundary of this region.

${ }^{4}$ Climatic Tables of the Japanese Empire, Tokyo: Central Meteorological Station, 1924. Records for 18 years or more, for Dairen, Ryojun, Yingkow, Mukden, and Changchun.

${ }^{5}$ Statistical Yearbook, Harbin: Chinese Eastern Railway, 1929, Appendix. Records for Manchouli, Buhedu, Anta, Harbin, Jaomen, Imienpo, Taipingling, and Sansing. ceives in excess of $600 \mathrm{~mm}$. and is forest clad. ${ }^{6}$

In winter, pressure and wind direction are reversed, and exceedingly dry, cold winds sweep over Manchuria from the north and northwest. Precipitation is in the form of snow, but the amount is small.

The temperature régime is typically continental, as is to be expected from the location on the east coast of a continent in the northern hemisphere. The mean annual temperature does not exceed $10^{\circ} \mathrm{C}$. except at the extreme southern tip of the Liaotung Peninsula. A relatively steady decrease takes place northward until, for a small section bordering the Amur, it is $2^{\circ} \mathrm{C}$. High elevations in the mountain country may well show a smaller figure.

The coldest month everywhere in Manchuria is January. At Dairen, the warmest station recorded, the January mean is $-5.1^{\circ} \mathrm{C}$. This drops steadily to $-27^{\circ} \mathrm{C}$. near the middle Amur. In the middle section of the plain, Changchun shows $-17.3^{\circ} \mathrm{C}$. and Mukden, $-13^{\circ} \mathrm{C}$. The warmest month is July. At Dairen $23^{\circ} \mathrm{C}$. is recorded, and along the middle Amur, $20^{\circ} \mathrm{C}$. In the Barga District, July means are between $17^{\circ}$ and $18^{\circ} \mathrm{C}$.

The temperature gradient is from south to north at all seasons, but is steeper and more regular in winter than in summer.

\section{Seasons}

All of Manchuria has at least five months with a mean temperature below $0^{\circ} \mathrm{C}^{7}$ In November, frost settles

\footnotetext{
${ }^{6}$ Generalized data on rainfall conditions may be secured from N. Murakoshi's "Rainfall Map of Manchuria and Mongolia," in Chu Coching, op. cit. Similar data on annual mean averages and means of maximum and minimum monthly temperatures may be had in Gauthier, H., La Température en Chine, 3 vols., 1918.

${ }^{7}$ Hann, J., Handbuch der Klimatologie, Vol. 3, pp. 303-313. Contains an excellent description
} 
in the ground and remains until March. The Liao River in the south is frozen over for four months, the Sungari in the central plain is frozen for five months, and the Amur in the far north is ice-bound for at least six months. During this winter period, cold, dry winds blow strongly from the northwest. The skies are extremely clear. Vigorous radiation takes place at night and strong insolation by day. What precipitation occurs falls as snow, and an accumulation of as much as one foot is exceedingly rare. The country roads are frozen hard and favor traffic. The severe, snow-free winter prohibits fall-sown crops, but limits rodent and insect pests.

In March the cold northwesters cease and warm, humid winds from the southwest set in. Wheat is planted in early April, although the subsoil is still frozen. Later in the same month, Indian corn and tobacco are planted. April is the only spring month, for in May summer begins. Beans, kaoliang and millet are planted the last days of April or in early May - the exact date varying from south to north. Until the end of June, only occasional light showers occur. This is far from ideal, and in some years the seeds fail to germinate because of excessive drought. In the last days of June and early July, the heavy rains begin. This is a time of violent storms. Often it pours continuously for several days. The rivers flood. The roads become quagmires. This lasts through August. Temperatures are then at the highest and all vegetation makes rapid growth. In September the rains cease and the warm, dry weather encourages rapid ripening. Beans are harvested between the 25th and the 30th of September; kaoliang and corn between the

of Manchurian weather but one which can be somewhat altered on the basis of more recent weather data. 20th and the 30th; and millet about the 15 th.

October is a month of nearly perfect weather-warm, dry, and sunny. Toward the end of the month the winds have completely shifted, and by November the first frosts tell the coming of another winter.

\section{Surface Divisions}

Morphologically, Manchuria may be divided into: (1) the mountainous lands of ancient rocks that surround the plain; (2) the plain lands of alluvial, low-lying flats and higher gravelly terraces which are drained by the Sungari and Liao rivers and their tributary streams; and (3) the continuation of the high Mongolian plateau which makes up the Barga District in the northwest.

\section{Eastern Mountain Land of Changpai}

Stretching from the northeastern corner of Manchuria, where the River Ussuri joins with the Amur, southeastward to the tip of the Liaotung Peninsula is a continuous mountain land known as the Changpai Range. This mountain mass, the length of which is over sixteen hundred kilometers and the maximum width of which near the center is six hundred kilometers, is composed chiefly of ancient rocksgneiss, granite, quartzite, mica schist, clay slate, porphyry, and diorite. ${ }^{8}$ These rocks are considered as older than Paleozoic, although their exact chronology is not known, because of the lack of detailed field work. Coalbearing tertiary formations are sometimes found resting unconformably upon these ancient rocks. While the tertiary beds everywhere show a tendency to folding parallel to the major trend of the range, the strike of

\footnotetext{
${ }^{8}$ Seuss, E., The Face of the Earth, Vol. 3, p. 123,
} 


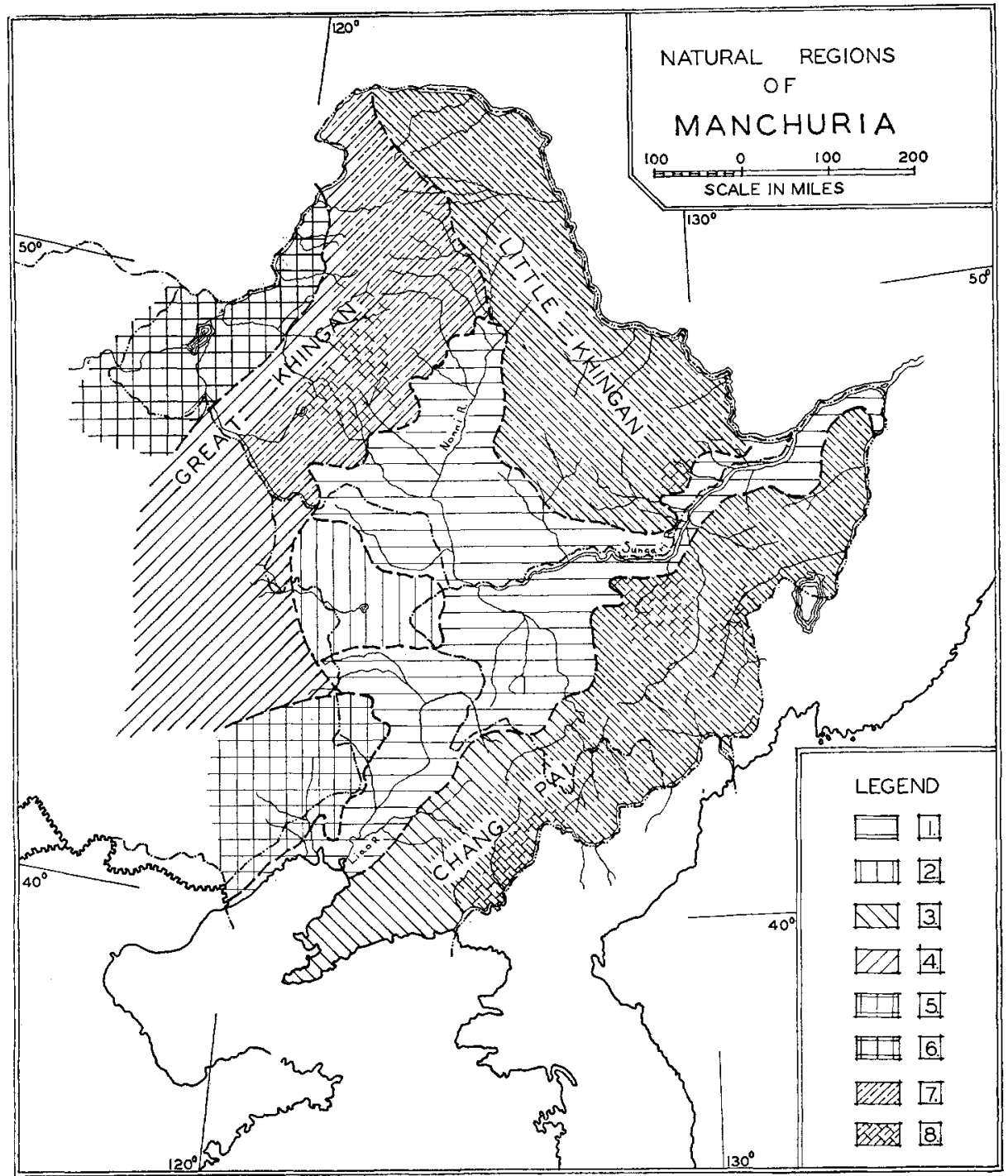

(1) Manchurian Plain; (2) Plain of Interior Drainage; (3) Worn-down mountains (Changpai and Little Khingan); (4) Dissected escarpment of Mongolian Plateau (Great Khingan); (5) Hill country of Jehol; (6) Plateau district of Barga; (7) Forests; (8) Areas of forest exploitation.

the older core rocks is somewhat deviated.

The culminative point of the Changpai Mountains is the giant volcano of Peik-tu-shan $(2400 \mathrm{~m}$.). Nine months of the year its peak is snow clad, and during midsummer it stands forth bare and pumice covered. A picturesque crater lake occupies its summit. Both north and south of this peak are found remnants of smaller volcanoes, ${ }^{9}$ several of which contain crater lakes. Rather recent basaltic flows are found near Ringuta, just south of where the

9 Sowerby, A. de C., "The Exploration of Manchuria," Geographical Journal, p. 180, 1919. 
Chinese Eastern Railway crosses the Changpai. ${ }^{10}$ One of these flows, blocking a valley, formed Lake Bertanwas.

In general, the Changpai is a subdued mountain land or one in the stage of late maturity. The northern portion has a general elevation of $600-700$ $\mathrm{m}$., and wide, old age valleys separate this section into several minor ranges. ${ }^{11}$ Both in width and elevation, the Changpai reaches its major proportions in its central portion. As this is also the rainiest part as well, many large streams find their headwaters here. Here, too, are excellent timber lands, and the production of timber is an important industry. Probably the world's finest ginseng is gathered here as well.

Southward, the Changpai decreases both in width and relief. Wide valleys between subdued uplands furnish good agricultural land and are densely populated. The valley slopes are gentle and concave. A gradual decrease in relief takes place southward until at the southern tip of the Liaotung Peninsula, only a rolling upland in old age is found. ${ }^{12}$ The average elevation of this extreme southern portion does not exceed $200 \mathrm{~m}$., but several prominent peaks protrude well above the general level. These are composed of quartzite and metamorphic limestone, and are regarded as monadnocks. ${ }^{13}$ Many of the Russian fortifications were built upon these prominences, and about them is the most famous battle field of the Russo-Japanese War.

The coast line of the Liaotung Peninsula is richly indented and shows recent submergence. A number of good harbors are found there, which

\footnotetext{
${ }^{10}$ Seuss, op. cit., p. 124.

$"$ "Seuss, op. cit.

12 Hanai, S., "Some Characteristic Features of the low-lying Peneplain of the Liaotung Peninsula," Geog. Rev. of Japan, Vol. 3, p. 650, 1928.

${ }^{13}$ Hanai, op. eit.
}

first attracted Russia and later, Japan.

Progradation is vigorous, and a number of ancient harbors have been abandoned as ports. ${ }^{14}$ Many small, off-shore islands are found separated from the mainland by submergence and probably in part by wave action. Some show definite peneplanation, but others are doubtlessly monadnocks protruding above the submerged level. The southeastern continuation of this peneplain accounts for the shallow waters off-shore in the Yellow Sea.

\section{The Khingan Mountains}

The Little Khingans lie between the plains of Manchuria and Siberia. Their general trend is N.N.W. to S.S.E. They are composed chiefly of gneiss and granite, but the northwestern portion is characterized by porphyry and basalt. ${ }^{15}$ Between the Little Khingans and the northern Changpai lies a saddle-like level, through which the Sungari cuts a narrow gorge.

In form, these mountains are quite similar to the northern half of the Changpai, in that they are generally subdued to late maturity, with wide valleys and gentle concave slopes. ${ }^{16}$ In the vicinity of Mergen, several small volcanoes containing distinct craters are found. Among them, Ujun Khaldongi is said to have erupted in 1712.17 Several recent lava flows are reported on both the south and the Amur sides.

Several large streams, tributaries of the Sungari, of which the Nonni and the Hulen Rivers are the largest, rise in the Little Khingans. This mountain land is forest clad throughout, but exploitation has been retarded on account of its isolation.

\footnotetext{
${ }^{14}$ Willis, B., and Blackwelder, E., Research in China, Vol. 1, pt. 1, pp. 86-87, 1907.

${ }^{15}$ Seuss, op. cit., p. 122.

16 Seuss, op cit.

${ }^{17}$ Seuss, op. cit., p. 120.
} 
The Great Khingan is not a mountain range or system in the true sense of the word, but rather the highly dissected and gigantic meridional scarp which separates the Mongolian plateau from the low-lying plains of Manchuria. The eastern slopes are high and rugged, but the western side merges gradually into the elevated peneplain of Mongolia. In the middle of the nineteenth century, Muschketon pronounced these mountains to be the result of profound faulting, marking the first step of the many descents in eastern Asia which culminate in the deeps of the Pacific. ${ }^{18}$ Richthofen took the same view. ${ }^{19}$ The southern end of the Great Khingan is supposed to be continuous with the outer border of the fault and flexure scarp of Shansi. Thus a great arc is drawn which presents its convex side to the southeast.

The northern part of the system receives adequate precipitation and is forest clad. The southern portion in Manchuria is generally treeless because of a lack of rainfall. Bad land topography is developed in some places.

\section{The Lumber Industry}

Unlike most of China proper, where three thousand years of exploitation has left barren slopes and a dire timber shortage, the mountain lands of Manchuria are still largely untouched. In spite of local and international interest, however, these timber resources are a wealth of unknown magnitude. Many sections, especially in the Great Khingans, are not well enough known to allow a reasonable estimate. One fact is certain - the area in forest is vast, and each new estimate places a higher acreage and timber reserve than has been previously made. ${ }^{20}$ The Chang-

\footnotetext{
${ }^{18}$ Seuss, op. cit., p. 120.

${ }^{19}$ Richthofen, F., China.

${ }^{20} \mathrm{Chu}$ Hsiao, op. cit., p. 14, shows the esti-
}

pai and the Little Khingans are natural forest lands and have not been exploited to any appreciable extent, as is true also of the northern portion of the Great Khingans.

The hill country in Fengtien Province and the valleys and lower slopes of the Changpai have been ruthlessly cut out. The Chinese came as farmers and burned away the forest where it interfered with agriculture. In many places in south Manchuria, the peasants are already relying upon the stalks of kaoliang and corn for fuel. Both Russian and Japanese have entered into the wholesale cutting of the Manchurian forests. Exploitation is confined to areas where transport is relatively easy. Such areas are found where the Chinese Eastern Railway crosses the Great Khingans and the Changpai, and where streams are large enough for logging. The Yalu, the upper Tumen, the Sungari, and the Hun are at present active transporters of $\log$ rafts. The cutting takes place chiefly in winter, and the logs are rafted out during the high water of the summer rains. The laborers enter the forests in late September, after the harvest is over on the plains.

Over three hundred species of trees have been identified, comprising eight coniferous and twenty-one broadleaf varieties. It is generally estimated that about forty per cent of the reserves are in conifers and sixty per cent in broadleaf trees. The Korean Pine is the finest of the conifers and is most abundant in eastern and northeastern Manchuria. Larch, fir, and spruce are widespread. The Siberian pine is common in the Great Khingan. Oaks, maple, elm, and poplar are important

mates from Chinese sources to have steadily increased from $3.7 \mathrm{mil}$. acres in 1914 to $30.5 \mathrm{mil}$. acres in 1927. A Japanese estimate in Report on Progress in Manchuria, pp. 124-125, 1929, is 88.8 million acres. 
broadleaf trees. Birch forests occur north of Tsitsihar and throughout the northern Great Khingans.

Thefollowing table, although possibly exaggerated, is as reliable as any and will give some notion of distribution. ${ }^{21}$

TABLE I

\begin{tabular}{|c|c|c|}
\hline Forest District & $\begin{array}{l}\text { Areas in } \\
\text { Millions } \\
\text { of Acres }\end{array}$ & $\begin{array}{l}\text { Million } \\
\text { Cubic } \\
\text { Feet of } \\
\text { Timber }\end{array}$ \\
\hline $\begin{array}{l}\text { Right bank of Yalu and } \\
\text { basin of Hun River... }\end{array}$ & 2.40 & 3.6 \\
\hline Upper Sungari . . . . . . . . & 3.52 & 8.7 \\
\hline Tumen Valley . . . . . . & 2.04 & 4.2 \\
\hline Hurka Valley....... & 1.55 & 4.2 \\
\hline Lalin Valley . . . . . . . . & 1.55 & 3.0 \\
\hline $\begin{array}{l}\text { Eastern section of Chi- } \\
\text { nese Eastern Railway }\end{array}$ & 5.96 & 8.98 \\
\hline Sansing . . . . . . . . . & 12.94 & 26.15 \\
\hline Great Khingan. . . . & 34.30 & 56.00 \\
\hline Little Khingan .. & 24.50 & 35.00 \\
\hline Totals . & 88.79 & 149.91 \\
\hline
\end{tabular}

The location of Manchuria between China and Japan, both countries deficient in timber, promises an active future trade. The commercial significance of timber is at present far inferior to that of agriculture. In 1927, forest products amounted to but 1.7 per cent of the total exports. The average annual estimated production of timber in Manchuria for the years 1923-1926 inclusive was 45 million cubic feet. The average import of timber for the same period was 7.4 million. Average export for the same period was 21.6 million, leaving a balance on home consumption of 30.8 million cubic feet.

\section{Other Industries of the Mountain LANDS}

Coal, iron, and gold are the chief minerals occurring in Manchuria, although very extensive deposits of 125.

${ }^{21}$ Report on Progress in Manchuria, pp. 124- brown coal are found in north Manchuria. The best coals and the greatest development of coal mining occur in the southern half of the Changpai mountains. A little copper is also produced there. Over one half of the iron reserves known to exist in China are found in this same mountain area. Gold is found chiefly in the Little Khingan region, although some occurs in the Changpai. All is alluvial.

The following table indicates the production of important minerals for Manchuria on the basis of 1925 data. ${ }^{22}$

\section{TABLE II}

\begin{tabular}{|c|c|}
\hline Mineral & $\begin{array}{c}\text { Value in U.S. } \\
\text { Dollars }\end{array}$ \\
\hline Coal and coke... & $39,702,625$ \\
\hline Gold . . . . . . . & $5,562,953$ \\
\hline Iron ore and pig. & $4,325,000$ \\
\hline Current. . . . . . . & $2,700,000$ \\
\hline Salt* ... & 980,000 \\
\hline Soda $\lceil\ldots \ldots \ldots \ldots \ldots$ & 601,000 \\
\hline Ceramic clay and kaolin. & 761,833 \\
\hline Lead, pig. ........... & 163,641 \\
\hline Talc $\ldots \ldots \ldots \ldots \ldots$ & 151,276 \\
\hline Copper. . & 139,710 \\
\hline Est. total of all production. . & $57,823,695$ \\
\hline
\end{tabular}

* Derived from the evaporation of sea water off the shores of southern Manchuria. A large percentage from the Kwantung Leased Territory.

tDerived from soil accumulations in the Nonni Valley of north Manchuria.

A word should be said here regarding the production of tussah or pongee silk and ginseng, both of which are confined to the southern part of the Changpai mountain country. The former is produced in the valley and lower slope areas, chiefly along the lower Yalu. Its production depends not upon the mulberry leaf, but rather upon the

${ }^{22}$ Torgasheff, B. P., "'The Mineral Wealth of North and South Manchuria," Chinese Economic Journal, Vol. 4, No. 1, pp. 28-30, Jan., 1924. 
foliage of various oaks. Most of this silk goes to Chefoo, on the north coast of the Shantung Peninsula, where it is made into the famous Shantung pongee. The annual value of production is about $\$ 4,000,000$, at least ninety per cent of the output being exported.

Ginseng, prized by the people of the Far East as a cure-all, was one of the magnets which drew the first Chinese settlers, and was for a long time one of the chief sources of income of the Manchu Dynasty. Purely an exploitative industry, it has almost disappeared.

\section{The Plain of Manchuria}

The plain of Manchuria forms a roughly oval shaped area, inclosed, except at the mouth of the Liao, by the mountain masses just discussed. This plain, originally a grassland, was occupied for centuries by nomadic tribes of herders. Today, it is the scene of possibly the greatest migration in human history. Its vast agricultural possibilities are finally being realized by the famished millions of Chinese to the south. Manchuria contains the last great area of middle latitude grasslands still untouched by the plow.

Morphologically, it is composed of gravelly terrace land (diluvium) excavated by valleys with wide alluvial plains. About two thirds of the Manchurian plain lies in the drainage basin of the River Sungari and its tributaries; something less than one third is drained by the Eastern, the Western, and the Great Liao; and the balance belongs to the endoreic domain.

The entire plain land may be roughly divided into three main natural divisions: (1) The Plain of the River Liao, (2) The Plain of the River Sungari and its tributaries, and (3) the Western Plain of interior drainage (part of inner Gobi or Eastern Inner Mongolia).

\section{The Liao Plain}

The Liao or Southern Plain stretches northeast-southwest, from the Gulf of Liaotung to about the latitude of Kirin and Changchun, between the foothills of Changpai and the hill country Jehol. This area lies in the sphere of the South Manchuria Railway and Japanese influence. Two subdivisions may be recognized; i.e., the south Liao Plain and the north Liao Plain, arbitrarily separated from each other at about Tungkiangkou.

The Southern Liao Plain is a broad alluvial plain bordered by terraces on the extreme margins. Over this area a thin covering of loess has been deposited. The best soils are the fresh alluvium of the delta, but periodic floods in places prohibit their use. The climate here is the mildest of the plain country, and crops such as tobacco and cotton do well. Paddy rice is of increasing importance.

For at least two centuries, Chinese coolies have been pouring into this region, until the density of population is now so great that it, too, has become a center of migration northward. The Liao River is navigable up to Chengchiatun, 550 miles from its mouth, and including portions of its tributaries there is a total navigable distance of 833 miles. However, it is very shallow in places, and only junks can be used. It is frozen, too, for about four months. Until the completion of the South Manchuria Railway it was the only gateway to the interior. Yingkow was then the one great port. Some twenty thousand junks are said to have plied the waters of the Liao in 1899. Today, but three thousand junks are employed, and Dairen, the terminal of the railroad, far surpasses Yingkow. The early settlement naturally followed up the Liao River, while the immigrants of today go inland from Dairen by rail. 
The Southern Liao Plain is today the most densely populated portion of Manchuria and is in many ways a detached remnant of the Plain of North China. Practically all arable land is intensively cultivated in a variety of crops. Kaoliang occupies more than fifty per cent of the cultivated land. Indian corn, too, is important. Small walled villages of mud houses are densely and evenly scattered over the plain. Kaoliang and corn stalks constitute the chief source of fuel and thatch.

The great majority of farmers are land owners in this section, but the average farm is exceedingly small. At least one fourth of the farms are not more than an acre in size, and not more than one fifth exceed ten acres. The value of good land is about $\$ 110$ per acre. ${ }^{23}$

The Northern Liao Plain is an extensive area of undulating land broken near the margins by higher terrace lands. It is a region of highly fertile black soils, but unlike the lands to the south, some of the natural grassland is left and the grazing industries are still significant. The settlement of this area has been exceedingly rapid in recent years, and population may soon exceed the saturation point. Kaoliang and corn are still important, but the soy bean and millet compete for primary place. Spring-sown wheat and barley are of increasing importance. The average size of farms has increased ten to thirty acres and tenantry is more common than along the lower Liao. The value of good land here is about $\$ 60 .{ }^{24}$

\section{The Sungari Plain}

The Plain of the River Sungari and its tributaries is an area of extensive

${ }^{23}$ Adachi, K., Manchuria: A Survey, p. 149, 1925.

${ }^{24}$ Adachi, op. cit. terrace land into which the many streams of north Manchuria have sunk their channels and built wide alluvial plains. This is the real frontier of Manchuria and the scene of the most active immigration. Its climate is distinctly continental, and long, severe winters occur.

The soy bean is all-important. Spring wheat reaches its major significance here. Much of the land is still uncultivated and supports a thriving grazing industry.

This is the land of Russian dominance and is served by the Chinese Eastern Railway. The Sungari, which is navigable for about six hundred miles, and its larger tributaries, which offer wide stretches of navigable water, are also important arteries of transport and communication. Two divisions may be recognized - eastern or Sungari, and western or Nonni.

The eastern or Sungari division lies eastward of about the longitude of Anta. This area is dominated by the main course of the Sungari River. Broad alluvial plains lie on either side of the river, but the most extensive ones occur to the north. Three forces can be recognized as affecting settlement and the present distribution of population. First, the direction of Chinese migration has been from the south; and as a result the oldest settlements and the densest population are found along the southern border, where rural density runs about eighty per square kilometer.

Second, the rivers furnish access to the interior and transportation for surplus products. In addition, the best soils are often found adjacent to the streams. As a result, settlement has pushed far along the immediate valleys of the Sungari and its tributaries.

Finally, the railroad gives many advantages to the settler, and relatively dense population is found near it. 
Agriculture is most important where population is densest and where transportation is best developed. Grazing is of greater relative importance elsewhere. The soy bean occupies about thirty-five per cent of all cultivated land, wheat twelve per cent, and millets sixteen per cent. ${ }^{25}$ Kaoliang and corn occupy thirteen per cent and seven per cent respectively, but are found chiefly along the southern border. Good farm lands sell at five to ten dollars per acre.

The western or Nonni section is dominated by the Nonni River and its tributaries and is the least settled of the fertile lands of Manchuria. It was until rather recently under the rule of Mongol chieftains and is today the most bandit-infested part of Manchuria. It has also the most severe climate and as a result it is but sparsely populated. Soy beans occupy about twenty-seven per cent of the cultivated

${ }^{25}$ Statistical Yearbook, Appendix and Economic Bureau, C. E. R.; The C. E. R. and its Zone, 1928, maps and statistical data. An interesting discussion of Manchurian agriculture from the Japanese point of view is found in Tanaka, H., "Agriculture in Manchuria and Mongolia," Chikyu-The Globe, Vol. 2, No. 2, pp. 42-48, 1924. An excellent set of agricultural maps and a résumé of agricultural conditions are given by Murakoshi, N., and Trewartha, G., "Land Utilization Maps of Manchuria," Geographical Review, Vol. 20, No. 3, pp. 480-494, 1930. land, millets twenty-one per cent, and wheat ten per cent. Cattle and horses are very numerous. Much of the land is still virgin grassland and is valued at one to three dollars an acre. Ranches of a thousand acres are not unknown.

The Western Plain of Interior Drainage lies at the foot of the Great Khingan and constitutes part of the area known as Inner Gobi or Eastern Inner Mongolia. It has recently come under the political control of Manchuria. This is a sandy basin plain containing several saline lakes and extensive saline flats. The extraction of soda from these lands is an ancient and important industry. A few nomadic herders tend their flocks as well.

\section{Agriculture}

Agriculture affords by far the chief income and the future wealth of Manchuria. Its application is and will be confined almost exclusively to the Manchurian plain, although valleys of the Changpai and the Little Khingan Mountains allow some development.

The following tables give fairly reliable estimates on present agricultural development by provinces and totals. Fengtien and southern Kirin contain the Plain of the River Liao, while northern Kirin and Heilungkiang con-

TABLE III-1927 26

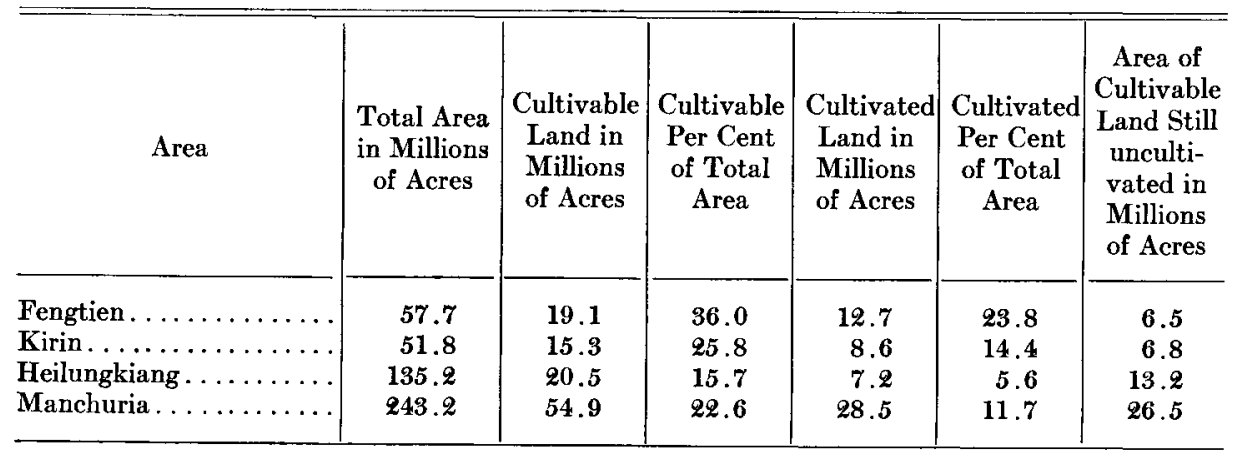

${ }^{26}$ From Diagrams of Current Statistics, Vol. II, pt. 3, Table 17, Statistical Soc. of Japan: 1928. 
TABLE IV-1927 27

\begin{tabular}{c|c|r|r|r|r|r|r|r}
\hline \hline Area & Barley & $\begin{array}{c}\text { Soy } \\
\text { Beans }\end{array}$ & Corn & Millets & Rice & Kaoliang & Wheat & $\begin{array}{c}\text { Total of } \\
\text { Seven } \\
\text { Main } \\
\text { Crops }\end{array}$ \\
\hline Fengtien...... & 200 & $\mathbf{2 , 0 6 4}$ & 1,380 & $\mathbf{1 , 6 3 8}$ & 215 & 3,249 & 210 & 8,956 \\
Kirin........ & 226 & 2,923 & 666 & 2,095 & 286 & 2,056 & 1,000 & 9,252 \\
Heilungkiang. . & 256 & $\mathbf{2 , 6 3 3}$ & 373 & $\mathbf{1 , 0 4 0}$ & 37 & 849 & $\mathbf{9 4 6}$ & $\mathbf{6 , 1 3 4}$ \\
Manchuria.... & $\mathbf{6 8 2}$ & $\mathbf{7 , 6 2 0}$ & 2,419 & $\mathbf{4 , 7 7 2}$ & 538 & $\mathbf{6 , 1 5 5}$ & $\mathbf{2 , 1 5 6}$ & $\mathbf{2 4 , 3 4 2}$ \\
\hline
\end{tabular}

:7 In thousands of acres. Yearbook of Manchuria-Mongolia, p. 490f, Manchuria Enlightening Society: 1928.

tain the plain of the River Sungari and its tributaries.

The total arable land of Manchuria is estimated at about fifty-five million acres, or about 22.6 per cent of the total area. Of this cultivable area, twentyeight million acres or about one half is now under cultivation. The per cent of arable land utilized for agriculture decreases from south to north. In Fengtien Province about two thirds is cultivated, in Kirin about one half, and in Heilungkiang about one third. As Heilungkiang also has the greatest area of arable land, as well, the greatest future development can be expected there. Likewise, the intensity of cultivation increases southward and so the greatest increases per unit of area can be expected in the north.

The most important crop of Manchuria is the soy bean. In fact, over one half of the world's soy bean production occurs in the Three Eastern Provinces. The average yield per acre is likewise outstanding, being twenty bushels to the acre, as compared with fifteen in the United States and fourteen in China proper. In commercial significance the soy bean far surpasses kaoliang, which has nearly the same acreage, for it furnishes the bulk of Manchurian export. The production of soy beans is gaining rapidly, both absolutely and relatively in regard to other crops. In 1914, it occupied $4,165,000$ acres, or twenty per cent of the cultivated land. By 1927, there was an almost two-time increase, or an acreage of 7,620,000 acres, which occupied 31.3 per cent of the crop land. Until 1917, Fengtien Province was the largest producer, but has since been passed by the other two provinces.

Kaoliang is almost entirely a sustenance crop and is confined to the southern half of the Manchurian plain. Corn is also chiefly found in the southern half, but it has been losing in recent years to kutze and the other millets.

Barga is a special district in northwest Manchuria, lying beyond the crest of the Great Khingans. It is in reality a part of the high Mongolian plateau and is extremely arid. Agriculture is but slightly developed and nearly impossible. Grazing, especially sheep, is the important industry. Deposits of brown coal occur and are mined for the Chinese Eastern Railway. Barga straddles the Chinese Eastern Railway where it enters Manchuria, and is the meeting place of many peoples. Its population includes Mongols, refugee Cossacks, Russians, Chinese, and Manchus. The great annual fair at Ganjur about a hundred miles from Hailar, is a picturesque institution and serves, commercially, a large area in adjacent Mongolia. 


\section{Composition of Popdlation}

The total population of Manchuria is a matter of conjecture. Estimates vary widely, but the more reliable ones of recent date would indicate a figure of about $25,000,000$. The racial composition of this population is about as follows: : $^{28}$

TABLE V

\begin{tabular}{|c|c|}
\hline Chinese. & $24,194,587$ \\
\hline Koreans............ & 452,362 \\
\hline Japanese. . . . . . . . . . . . . & 203,169 \\
\hline Tungus $\ldots \ldots \ldots \ldots \ldots \ldots \ldots$ & 771,189 \\
\hline Russians $\ldots \ldots \ldots \ldots \ldots \ldots$ & 80,000 \\
\hline Other Europeans...$\ldots \ldots \ldots$ & 5,000 \\
\hline Total population... & $25,706,307$ \\
\hline
\end{tabular}

The Chinese constitute the majority of rural population everywhere in Manchuria, except possibly in limited areas near the Korean border and in the northern mountain country. Chinese are the most numerous in all of the urban centers also. There, they constitute the majority of the farmers, laborers, and merchants, as well as contributing heavily to the professional classes.

The Koreans are most numerous in eastern Kirin Province, where they have extended paddy culture and where in places they exceed the Chinese in number. Koreans have been filtering into Manchuria for centuries and many have amalgamated with the Chinese. In all probability, the figure given above is too small.

The Japanese are found chiefly in the Kwantung leased territory and the zone of the South Manchuria Railway. About 51,000 are employed in agriculture, 75,000 in commerce and transportation, and 55,500 in manufacturing and mining, and 38,198 are classed as professional.

${ }^{28} \mathrm{Chu}$ Hsiao, op. cit., p. 40.
The Tungus, chiefly the last remnants of the Manchu peoples, are found still pursuing their primitive grazing industries in the Amur region, the northern mountain country, and the drier steppe lands.

The Russians prior to the war were employed chiefly in commerce and transportation centering about the Chinese Eastern Railway. This group has been supplemented by refugee White Russians. In Barga, refugee Cossacks are also found in considerable numbers. Russian reports usually give a figure in excess of 100,000 , and the figure of 80,000 may well be too small.

Europeans other than Russians are confined to the cities in which their commercial activities are allowed by treaty.

\section{Chinese, Russian, and Japanese SETTLEMENT}

The completeness of Russian rural economy, which is essentially that of Northern Europe, allowed the spectacular advance of the Russian settler across the world's widest land mass, finally reaching even to Alaska. Russian settlers reached north Manchuria from Europe in less time than Chinese settlement was able to penetrate beyond the lower Liao Valley. Chinese settlement, which is illustrative of the Far East, spreads as does a drop of oil. The rural economy demands the presence of markets and small-town industries. It involves tremendous numbers to occupy any appreciable area. Russian settlement, like that of the Anglo-Saxon in North America, moves forward by establishing detached bits far ahead of the urban frontier. However, the sparse and disseminated population established under the Russian system cannot persist before the onslaught of the massive tide of Chinese settlement. It will probably not be long before the last vestiges of the Rus- 
sian dream of Manchurian empire will pass into oblivion.

The Japanese attempt at rural settlement failed largely for two reasons. First, the semitropical material culture of the Japanese is not suited to Manchuria. The flimsy house without adequate heating facilities is not fitted to the long, severe, Manchurian winters. Rice cultivation is the heritage of the Japanese farmer and he is seldom happy in other types of farming. His general economy, too, has many of the characteristics of the Chinese and is not adapted to the frontier. Finally, the Japanese will not attempt to compete on the lower Chinese standard of living.

The rural Chinese are village dwellers where possible. In Manchuria, the need for protection from bandits makes village life most desirable. A low mud wall, with gates corresponding to the cardinal points of the compass and occasionally surmounted with turrets, surrounds most villages in the agricultural areas. Another common settlement form is the walled and strongly fortified estate of a large land owner surrounded by the dwellings of tenants and small farmers. The ordinary country house of the plains is a low rectangular hut of mud, thatched with kaoliang or corn stalks.

The rural population of the mountains is confined to the valleys and lower slopes, and tends to be disseminated. Here, the rural house is built of stone and timber.

\section{Urban Settlements}

Prior to the building of the railroads, the rivers afforded almost the only means of travel. The earlier towns then, with few exceptions, grew up along the rivers. The broad alluvial plains of the valley bottoms are often subject to flood, and in consequence the commonest urban site was on the valley bluff at a point where the river swung against it.

Two types of early town may be recognized. First, the towns which lie away from the present lines and have maintained a dominant oriental character. These towns are surrounded by mud and brick walls. The streets are narrow and unpaved. On either side of the streets are almost continuous lines of small shops. The buildings have tiled roofs and are of typically Chinese architecture. Second, many ancient towns have undergone great changes since the coming of the railroad. Rapid growth has characterized most of them. In some cases, the old town has grown first within the wall and finally burst beyond it. In other cases, the new town has grown up adjacent to the old. Harbin affords an excellent example.

The new developments in these ancient towns, as well as in the new towns which have grown up since the advent of the railroad, are of two types. Northern Manchuria is dominated by the Chinese Eastern Railway and Russian culture. The new towns in this district are characterized by a rectangular pattern of wide, unpaved streets and Russian architecture. One dominating feature always present is the half-oriental Orthodox church.

The more recent developments in south Manchuria are dominated by the Japanized Western elements. Dairen affords the best example. The streets are largely paved, better than in any city in Japan proper, and lie in a radial pattern with concentric connections. The buildings are straight-lined and largely of red brick. The Shinto shrine, an ever-present symbol of Japanese influence, is not missing here.

\section{Manufacturing}

Manchuria is primarily an agricultural country, and manufacturing in- 
dustries are but slightly developed. Those that do exist are of recent establishment and are chiefly confined to south Manchuria, where the densest populations and the oldest settlements occur. All important developments are found in the towns and cities adjacent to the railroads. The most highly developed are simple industries dependent upon local raw materials, chiefly agricultural. Mines and forests also contribute to some extent.

The pressing of oil from soy beans is by far the most important industry. The chief centers are Dairen, Harbin, Antung, and Newchwang, although many secondary towns located on the main-line railroads contribute to the production of these valuable export commodities. Flour milling is second in importance. Harbin is of first importance and contains twenty-three of Manchuria's fifty mills. At least half of the remaining mills are on the Chinese Eastern Railway. This is natural, as most of the wheat is grown in north Manchuria. The bulk of the flour produced is for local consumption. Distilling, beet sugar refining, tobacco manufacture, saw milling, coke and gas production, and a number of other industries, although of secondary importance, are none the less showing growth and promise for the future.

\section{Transportation}

The river systems of the Yalu and the Sungari, as has been previously noted, dominated traffic and communication prior to the coming of the railroad. They are still important as subsidiaries to the railroad. Especially is this true in the lumber industry. The settlements away from the railroads must depend entirely upon the rivers during the rainy season. Fortunately, when the rivers are frozen the country roads are hard and passable.
The first railroad construction dates to the end of the nineteenth century with a contract between the RussoChinese Bank and the Government of China for the construction and the maintenance of the Chinese Eastern Railway. Within the following thirty years, 3,500 miles of railroad were constructed; and Manchuria has today the best equipment, in this respect, of any part of China. Further construction is under way and projects indicate a possible future total of about six thousand miles.

The railroad is today the primary agent of settlement and trade, and, more than any other factor, has stimulated the extraordinary increase in production which has characterized Manchuria in recent years. The main line of the Chinese Eastern Railway is really a branch and short-cut of the Trans-Siberian Railroad which enters Manchuria at Manchouli and reaches the sea at Vladivostok. The South Manchurian Railway dominates south Manchuria and terminates in the Japanese leased territory of Kwantung.

The Chinese Peiping-Mukden line ties the Manchurian system with that of North China, while at Antung the railroads of Korea are tied to the South Manchurian Railway. The chief ocean ports serving Manchurian railways are the Japanese concession port of Dairen, the Russian port of Vladivostok, and the Chinese port of Yingkow.

\section{Trade}

Manchuria is a new and fertile land, and as such, has a relatively high per capita production. It is better served by railroads than is China proper. Its trade development has been rapid, and is characteristic and most illustrative of trade development in "exterior China." ${ }^{29}$ Although

${ }^{29}$ Remer, C. F., The Foreign Trade of China, p. 239, Shanghai: 1926 . 
Manchuria contains but one twelfth of the area of the Chinese Republic and but one sixteenth of its population, it accounts for nearly one third of China's total trade. In 1927, the per capita trade of all China was 4.8 taels; that of Manchuria was 23.8 taels, or more than five times greater. ${ }^{30}$ The development of Manchurian trade has been spectacular. From 1907 to 1927 the increase was from 51 million taels to 616.3 million, or over twelve times. During the same period, the total trade of all China increased but three times. Manchurian exports increased seventeen times and imports but 8.5 times from 1907 to 1927 , and a favorable trade balance is regularly maintained.

The exports, as is to be expected, are chiefly agricultural. Soy beans (26.9 per cent), bean cake (22.3 per cent), and bean oil ( 8 per cent), give to this important product 57.2 per cent of the total exports. Millet and kaoliang comprise 11.9 per cent. Other exports are: coal, 9.3 per cent; tussah silk, 2.7 per cent; timber, 1.7 per cent; pig iron, 1.6 per cent; and seeds, 1.1 per cent. No other product contributes over 1 per cent of the exports.

The imports are typical of those of new, nonindustrialized countries. They are chiefly manufactured goods. Cot-

\footnotetext{
${ }^{30}$ Trade data drawn from The Chinese Maritime Customs Reports, 1907 to 1927 inclusive, and the statistical yearbooks of the Chinese Eastern and South Manchurian Railways. All percentages are given in value and for the year of 1927 , unless otherwise stated.
}

ton textiles comprise 20.7 per cent; grain bags, 13.1 per cent; iron and steel, 6.4 per cent; and sugar, tobacco products, machinery, and so forth, all fall below 5 per cent.

Among the ports of Manchuria, Dairen ranks preëminent and accommodates 54.6 per cent of the total foreign trade. Antung holds a poor second place with 17.1 per cent. Both ports have shown large absolute and relative gains. Harbin was very prosperous before the revolution, but suffered considerable loss during it. In recent years it has regained some of its older importance and now handles 14.6 per cent of Manchuria's trade. Newchwang or Yingkow, the oldest port, now handles but 11.6 per cent. Aigun is credited with 2 per cent, and all other ports accommodate less than 2 per cent.

Japan ranks first among Manchuria's customers. This grows out of the Japanese control of south Manchuria and the complementary nature of the two countries. Japan's share of the total trade in 1927 was 39.3 per cent. Food, fertilizer, and coal were important items. China accounted for 30 per cent. Propinquity and the need for Manchurian foodstuffs in China account for most of the exports, while the desire for Chinese products among the new settlers accounts for most of the visible imports. Russia claimed 13.1 per cent, the United States 4.1 per cent, and all other countries less than 3 per cent. 